\title{
REVITALISASI BAHASA DAERAH UNTUK ANAK USIA DINI DI TK PERTIWI PURO PAKUALAMAN YOGYAKARTA
}

\author{
Windi Wulandari Iman Utama \\ Universitas PGRI Yogyakarta \\ windi@upy.ac.id
}

\begin{abstract}
ABSTRAK
Penelitian ini memiliki tujuan untuk memperoleh gambaran tentang revitalisasi bahasa daerah untuk anak usia dini. Penelitian ini dilakukan di TK Pertiwi Puro Pakualaman Yogyakarta. Penelitian ini menggunakan metode studi kasus dengan menggunakan pendekatan kualitatif. Analisis data model Milles and Hubberman digunakan dengan tahapan analisis data 1) reduksi data, 2) penyajian data, 3) verifikasi data. Dalam penelitian ini data diperoleh melalui : observasi, wawancara dan dokumentasi. Hasil temuan penelitian menunjukkan bahwa revitalisasi bahasa daerah untuk anak usia dini sangat diperlukan guna menumbuhkan pemahaman lebih dalam terkait bahasa daerah, rasa cinta dan rasa bangga memiliki bahasa daerah. Kesadaran ini diperlukan untuk melestarikan bahasa daerah agar tidak terkikis oleh perubahan zaman.
\end{abstract}

Kata Kunci: Revitalisasi, Bahasa Daerah, Anak Usia Dini

\begin{abstract}
This study aims to obtain an overview of the revitalization of local languages for early childhood. This research was conducted at TK Pertiwi Puro Pakualaman Yogyakarta. This research uses a case study method using a qualitative approach. Data analysis by Milles and Hubberman model was used with data analysis stages 1) data reduction, 2) data presentation, 3) data levers. In this study the data were obtained through: observation, interviews and documentation. The results of the research findings indicate that the revitalization of local languages for early childhood is needed to foster understanding that is more related to regional languages, a sense of love and a sense of pride in belonging to local languages. This awareness is needed to preserve regional languages so that they are not eroded by changing times.
\end{abstract}

Keywords: Revitalization, Local Language, Early Childhood

\section{A. PENDAHULUAN}

Pada era modern saat ini banyak dijumpai orang tua yang termotivasi untuk mengajari anak-anaknya bahasa asing sejak dini. Hal ini terlihat dari banyaknya tempat les privat bahasa asing yang membuka kelas untuk anak-anak maupun antusias orang tua yang menginginkan anaknya untuk masuk dalam sekolah yang menggunakan bahasa asing pada kegiatan sehari-harinya. Bahasa asing dianggap lebih bergengsi daripada bahasa ibu atau bahasa daerah. Asumsi ini muncul dikarenakan semakin banyak syarat untuk bekerja salah satunya adalah keahlian dalam berbahasa asing. Kenyataan yang terjadi ini menjadi penyebab terjadi krisis penggunaan bahasa daerah pada wilayah-wilayah di Indonesia. 
Bangsa Indonesia tercatat memiliki 707 bahasa daerah. Berbagai bahasa daerah termasuk bahasa jawa yang dimiliki oleh bangsa indonesia merupakan kekayaan yang tidak ternilai harganya. Ini merupakan kebanggaan sekaligus tantangan dalam mempertahankan keberadaan bahasa daerah pada masa modern ini. Realita yang terjadi adalah seiring perkembangan jaman ini semakin banyak orang tua dan pendidik yang kurang antusias dalam mengenalkan bahasa daerah kepada anak-anak. Baik dirumah maupun sekolah banyak yang menerapkan campuran bahasa asing pada setiap kegiatannya. Jika situasi ini tetap berlanjut maka tidak diragukan lagi bahwa keberadaan bahasa daerah bisa terancam punah. Hal ini sesuai dengan pendapat Lewis et al., (2015) yang menyatakan bahwa suatu bahasa dapat dikategorikan terancam punah apabila bahasa itu semakin sedikit digunakan dalam kegiatan sehari-hari sehingga kehilangan fungsi sosial atau fungsi komunikatifnya. Semakin kecil ranah penggunaan bahasa dalam masyarakat akan mempengaruhi persepsi pengguna bahasa.

Anak usia dini perlu dikenalkan bahasa daerahnya sebelum mengenal bahasa asing. Hal ini perlu dilakukan karena beberapa alasan diantaranya karena bahasa daerah merupakan bahasa warisan dari para leluhur atau nenek moyang yang harus dijaga kelestariannya. Setiap bahasa yang di miliki oleh bangsa Indonesia mempunyai keunikannya masing-masing. Salah satunya bahasa Jawa yang memiliki tingkatan dalam penggunaannya. Tingkatan dalam bahasa Jawa ini dijadikan sarana untuk mengatur sikap dan penyampaian komunikasi dalam berbicara. Bahasa Jawa sendiri memiliki dua tingkatan yaitu bahasa Jawa Ngoko dan bahasa Jawa Krama. Bahasa Jawa ngoko digunakan unntuk berbicara dengan sesama teman seumuran atau dengan orang yang lebih rendah derajatnya atau dipergunakan oleh orang tua kepada anak-anak yang lebih muda. Sedangkan bahasa Jawa Krama biasanya digunakan untuk orang yang sama-sama saling menghormati atau dipergunakan oleh anak muda kepada orang tua ataupun acaraacara resmi dan orang yang belum pernah bertemu sebelumnya.

Oleh karena itu tidak jarang peggunaan bahasa daerah yang tepat dianggap sebagai cermin nilai-nilai sopan santun atau tata krama. Pengunaan bahasa dengan beberapa tingkatannya ini secara tidak langsung akan membiasakan anak untuk menghormati orang yang lebih dewasa. Pembiasaan ini akan menghasilkan sikapsikap positif atau membentuk perilaku positif dalam diri anak. Anak akan memahami cara yang baik dan tepat dalam berkomunikasi dengan orang lain. Anak akan lebih dapat memposisikan dirinya ketika berhadapan dengan orang yang lebih dewasa. Lebih lanjut bahasa daerah merupakan bahasa ibu atau bahasa pertama yang seharusnya anak kuasai terlebih dahulu daripada bahasa asing. Bahasa ibu ini adalah bahasa daerah yang akan digunakan anak dalam kehidupan sehari-hari baik dirumah, di lingkungan sekolah maupun di lingkungan tempat tinggalnya. Anak usia dini sedang berada pada masa perkembangan dan pertumbuhan yang sangat pesat, maka masa ini adalah masa yang tepat untuk mengajarkan bahasa daerah anak sebelum mengenal bahasa asing. Sangat perlu 
memperkenalkan bahasa daerah ini dikarenakan anak akan menggunakannya untuk berinteraksi dengan lingkungannya yang mengggunakan bahasa daerahnya. Ada dampak yang akan muncul jika anak terus menerus dijejali bahasa asing pada masa usia dini, anak akan merasa kebingungan. Fase ini terjadi saat anak tidak mampu menyerap bahasa dengan sempurna karena belum memliki pegangan kuat dalam berbahasa. Penggunaan bahasa daerah sebagai bahasa pertama anak sangat disarankan agar anak tidak mengalami kebingungan, hal ini dapat dilakukan melalui dukungan dari keluarga khususnya orang tua dan lingkungan sekitarnya. Bahasa awal pada anak usia dini perlu ditanamkan dengan hati-hati dan tepat agar anak dapat berkomunikasi dengan sangat baik dalam proses interaksi sosial dengan lingkungannya. Pendidik maupun orang tua sangat memegang peranan penting dalam pembiasaan menggunakan bahasa daerah untuk anak-anak. Seperti yang dilakukan oleh pendidik di TK Pertiwi Puro Pakualaman yang memliki strategi dalam kegiatan belajar mengajar sehari-hari disekolah dengan menggunakan bahasa daerah khususnya bahasa Jawa. TK Pertiwi Puro Pakualama sebagai lembaga pendidikan anak usia dini yang berada di kota Yogyakarta menyadari pentingnya pengenalan serta pembiasaan penggunaan bahasa daerah sebagai bahasa awal untuk anak. Revitalisasi bahasa daerah untuk anak usia dini di TK Pertiwi Puro Pakualaman inilah yang menjadi perhatian peneliti untuk melakukan penelitian lebih lanjut.

\section{B. METODE PENELITIAN}

Metode penelitian yang dilakukan menggunakan metode studi kasus dengan pendekatan kualitatif. Myrnawati (2012) menegaskan bahwa penelitian kualitatif digunakan dalam memperoleh pemahaman mendalam terkait dengan perilaku, sikap kepercayaan, dan motivasi tertentu. Melalui pendekatan kualitif, peneliti bertujuan agar memperoleh informasi secara mendalam dan terperinci. Lebih lanjut Sugiyono (2011) menyatakan bahwa pengumpulan data dapat dilakukan dengan mengumpulkan data terkait revitalisasi bahasa daerah untuk anak usia dini melalui wawancara, observasi dan dokumentasi. Selanjutnya teknik analisis data model Milles anda Huberman digunakan dengan langkah sebagai berikut 1) Reduksi data, 2) Penyajian data, 3) Verfikasi data.

\section{PEMBAHASAN}

Revitalisasi bahasa daerah di TK Pertiwi Puro Pakualaman dilakukan secara menyeluruh dalam setiap kegiatannya. Hal ini dilakukan agara anak terbiasa dan mampu memahami serta menerapkan bahasa daerah khususnya bahasa Jawa. Menurut Hinton (2011), revitalisasi bahasa merupakan upaya dalam mengembalikan bahasa yang terancam punah setelah mengalami penurunan penggunaan. Lebih lanjut Hinton menyatakankan bahwa tugas paling utama dalam revitalisasi bahasa diantaranya 1) mengajarkan dan membiasakan bahasa kepada 
yang tidak mengetahui bahasa tersebut serta 2) membuat yang mempelajari dan yang sudah memahami bahasa tersebut dapat menggunakan dalam berbagai situasi. Strategi dalam revitalisasi bahasa daerah untuk anak usia dini dilakukan dalam pembiasaan kegiatan sehari-hari. Kegiatan disekolah $80 \%$ menggunakan bahasa daerah sesuai dengan tingkatan tata bahasa Jawa yang ada. Lebih lanjut sekolah berkoordinasi dengan orang tua ataupun walimurid agar dapat menggunakan bahasa daerah saat berkomunikasi dengan anak-anak dirumah. Hal ini dilakukan agar penggunaan bahasa dapat selaras baik dirumah maupun disekolah serta menghindari fase kebingungan yang akan dialami oleh anak. Dengan begitu upaya-upaya pendidik akan lebih efektif karena anak mendapatkan pengalaman secara nyata. Sejalan dalam Guslinda (2018) berdasarkan kerucut pengalaman Edgar Dale yang menegaskan bahwa untuk pemerolehan pemahaman melalui pengalaman nyata seperti bermain peran ataupun melakukan hal nyata sehingga pengalaman belajar anak lebih konkret dimana $90 \%$ yang telah dilakukan akan mudah diingat dan dipahami.

Proses kegiatan belajar mengajar di TK Pertiwi Puro Pakualaman dilakukan dalam beberapa tahapan kegiatan: 1) Kegiatan awal dilakukan dengan mengkondisikan anak-anak untuk memulai kegiatan disekolah. Diawali dengan berdoa bersama dengan menggunakan bahasa Jawa dilanjutkan bernyanyi serta percakapan pembuka dengan menggunakan bahasa Jawa dengan anak-anak. Pendidik mengarahkan dan mendampingi anak yang belum bisa menggunakan bahasa Jawa dengan tepat. 2) Kegiatan inti diisi dengan pemberian kegiatan terstruktur untuk anak-anak. Dalam memberikan arahan dalam kegiatan inti, pendidik menggunakan bahasa Jawa sebagai penghantarnya. Tanya jawab yang tawarkan untuk anak yang kurang memahami arahan dalam kegiatan inti juga menggunakan bahasa Jawa. 3) Istirahat, pada saat istirahat guru mendampingi anak dan mengarahkana nak untuk menggunakan bahasa sesuai dengan tingkatannya. 4) Kegiatan penutup, biasanya kegiatan penutup dilakukan dengan menreview kegiatan-kegiatan yang telah dilalui. Percakapan dan doa penutup kegiatan menggunakan bahasa Jawa. Hal tersebut sesuai dengan yang dinyatakan oleh Hinton yang menegaskan beberapa upaya dalam mengembalikan penggunaan bahasa yang hampir punah, diantaranya yaitu: 1) Belajar beberapa kata, seperti salam atau percakapan pendek. 2) Mengumpulkan publikasi linguistik, catatan lapangan dan rekaman suara sebagai bagian dari penciptaan sumber daya berbasis masyarakat. 3) Membuat rekaman audio atau video dari penutur yang tersisa dengan tujuan mendokumentasikan dan mengarsipkan contoh penggunaan bahasa. 4) Menjalankan sekolah imersi penuh (sekolah yang bahasa pengantarnya adalah bahasa yang terancam punah itu sendiri) untuk anak-anak pada masyarakat yang memiliki sumber daya untuk mendukung mereka.

Anak-anak di TK Pertiwi Puro Pakualaman Yogyakarta dibiasakan menggunakan bahasa daerah sesuai dengan tingkatan bahasa Jawa yang ada misalnya bahasa ngoko boleh digunakan untuk anak yang lebih kecil atau untuk 
teman sebaya dan bahasa krama digunakan untuk anak yang lebih dewasa serta ibu guru ataupun orang tua dilingkungan anak. Pembiasaan ini secara tidak langsung memunculkan perilaku positif dalam diri anak diantaranya rasa saling menghormati serta adap sopan santun yang tumbuh pada diri mereka. Selain sopan santun, pembiasaaan ini menimbulkan rasa cinta dan rasa bangga memiliki bahasa daerahnya sehingga jika hal ini terus berlanjut hingga jenjang yang lebih tinggi akan menjadi sarana guna kelestarian bahasa daerah yang dimiliki.

\section{SIMPULAN}

Revitalisasi bahasa daerah untuk anak usia dini di TK Pertiwi Puro Pakualaman Yogyakarta menunjukkan hasil yang baik. Melalui pembiasaan dan arahan yang dilakukan disekolah membentuk perilaku positif, menumbuhkan pemahaman, serta menumbuhkan rasa memiliki bahasa daerah yang harus dilestarikan dengan cara menggunakannya dalam kehidupan sehari-hari. Hal ini akan menjadi pondasi awal untuk anak-anak dalam membangun kesadaran untuk menjaga kelestarian bahasa daerah agar tidak terkikis oleh perubahan jaman. Serta menghindarkan anak dari fase kebingungan bahasa sebelum mengenal bahasa asing yang akan anak dapat pada jenjang pendidikan selanjutnya.

\section{DAFTAR PUSTAKA}

Guslinda \& Rita K. (2018). Media Pembelajaran Anak Usia Dini. Surabaya: Jagad Publishing.

Hinton, Leanne. (2011). Revitalization of Endangered Language. Dalam Peter K. Austin dan Julia Sallabank, eds, The Cambridge Handbook of Endangered Languages. Cambridge: Cambridge University Press.

Sugiyono. (2006). Memahami Penelitian Kualitatif, Bandung: Alfabeta.

Lewis, M. Paul, Gary F. Simons, dan Charles D. Fennig (eds.). (2015). Ethnologue: Language of the World, Eighteenth edition. Dallas, Texas: SIL International. Diakses dari versi daring: http://www.ethnologue.com pada 19 Agustus 2015.

Linda Cambell. (2006). Metode Praktis Pembelajaran Berbasis Multiple Intelegences. Depok: Intuisi Press.

May Lwin. (2003). Cara Mengembangkan Berbagai Komponen Kecerdasan. Jakarta:Indeks

Myrnawati Crie Handini. (2012). Metodologi Penelitian untuk Pemula (Jakarta: FIP Press. 